\title{
Inovasi Pembelajaran Berbasis Aplikasi Mobile Pada Masa Pandemi Covid-19
}

\author{
Sidiq Aditia \\ Email: sidiqaditia@gmail.com \\ Program Studi Pendidikan Bahasa dan Sastra Indonesia
}

\section{Pengantar}

Pada masa pandemi covid-19 yang melanda seluruh dunia termasuk negara Indonesia yang mengakibatkan aktifitas tatap muka dan interaksi sosial secara langsung dibatasi. Hal ini sesuai dengan kebijakan Pembatasan Sosial Berskala Besar (PSBB) yang telah ditetapakan dan juga dijalankan oleh Pemerintah Pusat maupun daerah sebagai upaya menahan laju penyebaran virus covid-19 yang berdampak pada seluruh bidang kehidupan manusia tidak terkecuali bidang pendidikan. Tepat pada tanggal 17 maret 2020, Pemerintah Republik Indonesia melalui Kementerian Pendidikan dan Kebudayaan Republik Indonesia metapkannya pembelajaran secara online atau yang dikenal dengan istilah daring (dalam jaringan) di lembaga pendidikan seperti sekolah dan perguruan tinggi dengan hal ini diputuskan dalam surat edaran Nomor 4 Tahun $2020 .^{2}$ Hal ini membuat guru dan peserta didik mencari solusi dengan membuat inovasi-inovasi pembelajaran secara daring.

Walaupun sebenarnya pembelajaran secara daring tanpa disadari telah lama dilakukan dan dimanfaatkan oleh guru dan peserta didik dengan menggunakan aplikasi mobile tanpa mereka sadarai seperti menonton video pembelajaran baik yang berkaitan dengan lembaga pendidikan maupun umum di aplikasi streaming youtube dan tanpa disadari juga bila guru dan peserta didik mencari referensi atau bahan bacaan selalu tidak terlepas pada mesin pencarian google dan masih banyak contoh lainnya. Semua itu bisa dilakukan kapanpun dan dimanapun dengan memanfaatkan aplikasi mobile.

Menurut Zulhafizh \&Permatasari (2020) berbagai kebijakan muncul akibat adanya Covid-19. Aktivitas pendidikan dan pembelajaran menjadi persoalan besar sebab ada banyak aktivitas yang tidak cukup secara teoritis tetapi juga praktis. Keadaan ini mengubah tindakan yang semestinya dilakukan secara langsung atau bertatap muka antara pendidik dan peserta didik terhenti dan terbatas. 
Dalam kontek belajar daring di masa covid-19, kualitas belajar tidak diharapkan menurun tetapi terus meningkat. Jika kualitas belajar menurun, maka dapat memberikan dampak mutu capaian belajar wawasan dan pengalamannya (Zulhafizh, Atmazaki, \& Syahrul, 2013).

Tapi ada yang berbeda pada saat sebelum dan saat pandemi covid-19 jika pada saat sebelum guru dan peserta didik hanya memanfaatkan sebagai media informasi saja tetapi saat pandemi covid-19 terjadi guru dan peserta didik sangat memanfaatkannya sebagai media pembelajaran. Pengembang dan developer aplikasi juga tidak mau ketinggalan dengan adanya peluang yang mengguntungkan sehingga banyak aplikasi berlomba-lomba berinovasi dalam pembelajaran. Tidak hanya penggembang dan developer adapun guru dan siswa sebagai objek pengguna aplikasi mobile juga berinovasi dalam menggunakan dan memanfaatkan aplikasi mobile dalam menunjang pembelajaran secara daring.

\section{Inovasi Pembelajaran}

Inovasi adalah sebuah pembahruan yang bisa berupa ide, objek, produk, karya dan lain-lain. Yang mana dengan menggembangkan atau menggabungkan hal yang sudah ada hingga terlihat baru. Sedangkan proses pembelajaran adalah sebuah kegiatan yang dilakukan oleh guru dan peserta didik atau individu maupun kelompok dalam belajar. Jadi, Inovasi pembelajaran adalah sebuah kegiatan belajar yang dilakukan oleh guru dan peserta didik atau individu dan kelompok dengan cara baru atau inovatif dalam proses belajar.

Menurut (Rohma, 2014; Faturohman 2020; Lubis dkk, 2020) inovasi pembelajaran adalah pembaharuan pembelajaran yang ada sebelumnya kemudian dikemas atas dorongan gagasan barunya yang merupakan produk dari learning how to learn untuk melakukan langkah-langkah belajar, sehingga memperoleh kemajuan hasil belajar.

Menurut (Sa'ud, 2016; Iriansyah, 2020) inovasi pembelajaran disini dimaksudkan adalah sesuatu perubahan yang baru dan bersifat kualitatis, tentunya ada yang membedakan dari yang ada sebelumnya, dan dengan sengaja dibuat untuk 
meningkatkan dalam upaya pencapaian tujuan pembelajaran. Sedangkan yang dimaksud kata "baru" dalam hal tersebut adalah terkait apa saja yang belum dipahami atau dilaksanakan oleh penerima inovasi.

Dengan demikian, Inovasi pembelajaran merupakan sebuah kegiatan pembahruan pembelejaran yang dilakukan oleh guru dalam proses pembelajaran dengan melakukan inovasi dengan pembelajaran yang sudah ada kemudian menambahkan ideide, pemikiran atau gagasan yang baru. Dalam menciptakan inovasi-inovasi pembelajaran membutuhkan peran guru sebagai orang yang menciptakannya dan kerjasama peserta didik dalam proses pembelajaran. Sehingga proses pembelajaran yang inovatif bisa berjalan lancar karena Inovasi-inovasi pembelajaran terlahir dari pemikirin yang kreatif sehingga terciptakanya pembelajaran yang inovatif.

Pembelajaran yang inovatif perlu dilakukan agar menghasilkan output pembelajaran yang lebih baik dari pada sebelumnya, disamping berbagai tantangan dan perkembangan ilmu pengetahuan dan teknologi menghendaki adanya pembaharuan dalam pembelajaran tersebut. Dalam pembaharuan pembelajaran diperlukan agen pembaharuan dimana guru memiliki peran yang besar dalam pembaharuan tersebut. Agar pembelajaran inovatif, diperlukan guru yang inovatif dan kreatif terlebih dahulu. Dengan kreatifitas yang dimiliki oleh guru maka inovasi dapat dihasilkan olehnya.

Menurut Kuworo dkk (2019) Dalam inovasi pembelajaran, guru dapat mengembangkan berbagai model dan metode yang dimilikinya untuk diterapkan dalam pembelajaran disekolah. Sekolah sebagai sebuah institusi pendidikan memiliki sistem yang didalamnya terdiri dari berbagai komponen dan elemen.

Menurut Wulandari dkk (2018) Model pembelajaran mobile learning dapat memusatkan perhatian pada siswa (student centered learning) dengan cara guru sebagai fasilitator dan menyediakan media pembelajaran sehingga dapat menyajikan konten pembelajaran dalam bentuk teks, video, animasi dan multimedia.

Hal ini dijelaskan oleh Hapsari dkk (2017) Adanya konsep mobile learning, pembelajaran tidak akan dibatasi oleh ruang dan waktu karena fleksibilitas dan portabilitas perangkat yang digunakan sehingga siswa lebih antusias dan memiliki kesempatan belajar dengan ruang pembelajaran yang baru, mudah, bermanfaat, dan 
menyenangkan. Mobile learning berbasis android dapat dijadikan alat belajar yang berisi materi pembelajaran, seperti: rangkuman materi, soal, animasi, video dan fitur lain yang lebih menarik. Aplikasi media pembelajaran menggunakan smartphone berbasis android terbukti layak, praktis, dan efisien untuk digunakan dalam pembelajaran (Lu'mu, 2017).

Pengembangan inovasi menurut Dewi (dalam Nurdyansyah \& Widodo 2015) pembelajaran dapat dilakukan dari beberapa hal. Demikian pula pengembangan inovasi. Seperti yang yang diuraikan dibawah ini :

1. Faktor Tak Terduga, Berbagai peristiwa yang menimpa individu ataupun organisasi apapun itu baik bisnis, politik, hukum ataupun pendidikan secara tak terduga baik itu suatu kesuksesan, kegagalan ataupun kejadian yang diluar prediksi bisa memotivasi untuk menemukan berbagai inovasi. Inovasi pendidikan atau inovasi pembelajaran digunakan untuk mendukung perbaikan akan kualitas proses pembelajran bisa lebih baik lagi. Tidak terjebak pada kondisi yang ada sehingga Peserta didik terhindar dari proses pembelajaran yang menjenuhkan.

2. Kesenjangan (Gap), Kesenjangan yang merupakan kondisi yang terjadi namun tidak sesuai dengan apa yang diharapkan. Hal inimenyebabkan timbulnya gap dengan harapan yang sudah ditetapkan. Jadi ada kondisi yang tidak ideal dan realita yang tidak sesuai dengan apa yang diharapkan. Hal inilah yang bisa diatasi dengan membuat inovas-inovasi diluar prosedur yang ditetapkan.

3. Kebutuhan Proses, Dalam melaksanakan berbagai aktivitas, selalu muncul pertanyaan tentang "apa" dan "bagaimana" proses aktivitas pembelajaran itu berlangsung. Karena inilah maka selalu setiap manusia menggunakan berbagai cara yang efektif kreatif dan inovati agar mencapai apa yang ditargetkan

4. Perubahan Persepsi, Persepsi merupakan cara pandang terhadap suatu hal ataupun suatu kejadian yang dihadapi seseorang. Persepsi dipengaruhi oleh pola berfikir, tatanan nilai, dan keyakinan yang dimiliki.

5. Keilmuan Baru, Saat ini keilmuan hampi di semua bidang mengalami perkembangan cepat dan pesat, mulai dari keilmuan kesehatan, sains dan teknologi, pendidikan dan yang lainnya. Perkembangan berbagai keilmuan ini mendorong 
adanya inovasi pembelajaran baik dari sisi metode, strategi ataupun media pembelajarannya. Pengembangan inovasi pembelajaran dilakukan dengan cara mengadopsi model-model pembelajaran menyenangkan yang bisa membuat Peserta didik tidak jenah selama pembelajaran berlangsung. Melalui model pembelajaran inovatif, peserta didik akan terbebas dari perasaan bosan, jenuh, khawatir akan kegagalan atau perasaan tertekan dalam melaksanakan berbagai tugas dll.

Dengan demikian pengembangan inovasi pembelajaran terjadi karena beberapa hal yang terjadi pada guru, peserta didik, masyarakat umum dan juga pemerintah sehingga memunculkan inovasi yang baru.

\section{Pemanfaatan Aplikasi Mobile Dalam Inovasi Pembelajaran}

Aplikasi mobile sekarang sudah sangat banyak digunakan dan tersedia secara gratis yang tujuannya sangatlah beragam salah satunya dalam pembelajaran. Apalagi saat ini aplikasi mobile telah banyak digunakan seiring semakin mudahnya mendapatkan gawai.

Menurut (Afandi \& Saputra, 2013; Irsan 2015; Trisnadoli, 2015) Aplikasi Mobile adalah perangkat lunak yang berjalan pada perangkat mobile seperti smartphone atau tablet PC. Aplikasi Mobile juga dikenal sebagai aplikasi yang dapat diunduh dan memiliki fungsi tertentu sehingga menambah fungsionalitas dari perangkat mobile itu sendiri. Untuk mendapatkan mobile application yang diinginkan, user dapat mengunduhnya melalui situs tertentu sesuai dengan sistem operasi yang dimiliki. Google Play dan iTunes merupakan beberapa contoh dari situs yang menyediakan beragam aplikasi bagi pengguna Android dan iOS untuk mengunduh aplikasi yang diinginkan.

Menurut (Layona \& Yulianto, 2016; Surahman \& Setiawan, 2017) Aplikasi mobile adalah sebuah aplikasi yang memungkinkan untuk melakukan mobilitas dengan menggunakan perlengkapan seperti PDA, telepon seluler atau handphone. Dengan menggunakan aplikasi mobile, maka dapat dengan mudah melakukan berbagai macam aktifitas mulai dari hiburan, berjualan, belajar, mengerjakan pekerjaan kantor, browsing dan lain sebagainya. 
Aplikasi mobile dalam pembelajaran atau mobile learning didisain untuk peserta didik. Menurut Abdullah \& Azelin (2010) mobile learning menawarkan beberapa kemudahan bagi penggunanya, antara lain tidak diperlukannya ruang kelas, karena materi pembelajaran dan pembelajaran dapat diperoleh dan dilakukan dimana saja dan kapan saja. Aplikasi mobile untuk pembelajaran biasanya memiliki tampilan antarmuka yang sangat kompleks dengan berbagai lapisan menu, sehingga aplikasi mobile perlu didisain dan dikembangkan agar menjadi lebih atraktif dan user friendly supaya dapat diterima oleh penggunanya.

Ada beberapa aplikasi mobile yang dimanfaatkan untuk proses pembelajaran sebagai berikut:

\section{Whatsapp}

Menurut (Prajana, 2017; Indaryani \& Suliworo, 2018; Amal, 2019; Hutami \& Nugraheni, 2020) media sosial WhatsApp yang sering disingkat (WA) adalah media komunikasi yang bisa di install dalam smartphone. Media sosial ini digunakan sebagai sarana komunikasi chat dengan saling mengirim pesan teks, gambar, video bahkan telepon. Media ini dapat aktif jika kartu telpon pengguna memiliki paket data internet.

Inovasi pembelajaran melalui aplikasi mobile WhatsApp pada masa pandemi covid-19 sangat beragam caranya. Dengan memanfaatkan fitur aplikasi WhatsApp salah satunya grup WhatsApp yang bisa berisikan dua ratus peserta dan juga ada fasilitas tambahan yakni voice note, video call, telepon, membagikan foto, video pendek dan juga dokumen.

Jadi, media sosial WhatsApp disingkat (WA) adalah aplikasi berbasis media komunikasi yang bisa di install dalam sistem iOS, Android bahkan Windows. Media komunikasi ini digunakan sebagai sarana komunikasi pesan berupa teks, gambar, video bahkan telepon antar penggunanya. Media ini dapat aktif jika memiliki data internet.

Inovasi-inovasi proses pembelajaran melalui aplikasi mobile WhatsApp dari beberapa penelitian sebagai berikut:

Pertama dari penelitian Meyda Setyana Hutami dan Aninditya Sri Nugraheni pada tahun 2020 berjudul "Metode Pembelajaran Melalui Whatsapp Group Sebagai 
Antisipasi Penyebaran Covid-19 pada AUD di TK ABA Kleco Kotagede." Dalam jurnal PAUDIA: Jurnal Penelitian dalam Bidang Pendidikan Anak Usia Dini yang membahas mengenai penggunaan WhatsApp Grup pada kegiatan belajar dari rumah di lembaga PAUD.

Kedua dari penelitian Eka Indaryani, dan Dwi Suliworo 2018 yang berjudul “Dampak Pemanfaatan WhatsApp Dalam Meningkatkan Motivasi Belajar Siswa Pada Pelajaran Fisika”. Dalam seminar Quantum: Seminar Nasional Fisika, dan Pendidikan Fisika yang membahas mengenai peningkatan hasil belajar siswa yang signifikan sebelum dan sesudah menerapkan dampak pemanfaatan WhatsApp dalam meningkatkan motivasi belajar siswa pada pelajaran fisika.

Ketiga dari penelitian Andika Prajana pada tahun 2017 yang berjudul "Pemanfaatan Aplikasi WhatsApp Dalam Media Pembelajaran Di Uin Ar-Raniry Banda Aceh”. Dalam jurnal Cyberspace: Jurnal Pendidikan Teknologi Informasi yang membahas mengenai pembelajaran tatap muka di kelas dengan pembelajaran dalam jaringan (daring) yang menggunakan aplikasi WhatsApp dengan pendekatan model pembelajaran kolaboratif.

Keempat dari penelitian Bakhrul Khair Amal pada tahun 2019 yang berjudul “Pembelajaran Blended Learning Melalui WhatsApp Group (WAG)”. Dalam Prosiding Seminar Nasional Fakultas Ilmu Sosial Universitas Negeri Medan yang membahas mengenai model pembelajaran Blended Learning melalui WhatsApp Group (WAG) memfasilitasi peserta didik selama proses pembelajaran. Dengan diterapkannya model Blended Learning ini, diharapkan dapat membuat siswa lebih tertarik untuk mengikuti kegiatan belajar di dalam maupun luar kelas.

Jadi, aplikasi mobile Whatsapp tidak hanya berfungsi sebagai aplikasi komunikasi saja amun juga bisa berfungsi sebagai aplikasi mobile pembelajaran yang mana sudah banyak di terapkan dan dilakukan yang membuat aplikasi mobile WhatsApp menjadi salah satu media pembelajaran yang digunakan dalam mendukung proses pembelajaran dimasa pandemi covid-19. 


\section{Telegram}

Menurut (Bambang, 2014; Septia, 2019) telegram adalah sebuah aplikasi messaging dengan beberapa keuanggulannya yang mana bukan hanya sekedar untuk aplikasi chating atau messaging. Telegram memberikan kualitas yang baik bukan hanya sekedar dari fiture untuk chating atau messaging saja, akan tetapi memberikan kecepatan dan keamanan, mudah digunakan dan free.

Selain itu menurut Karyadi (2018) aplikasi ini juga dapat digunakan di semua perangkat pada waktu yang sama pesan dapat tersyncron dengan baik di salah satu ponsel kita, tablet atau komputer. Dengan Telegram, Kita dapat mengirim pesan, foto, video dan file dari setiap jenis ( $d o c$, zip, $m p 3$, dll) kepada orang-orang yang berada dalam kontak telepon dan telegram. Kemudian juga dapat membuat grup melebihi dua ratus orang atau membroadcast hingga seratus kontak. Sehingga, dan dapat memenuhi semua kebutuhan pesan pribadi atau bisnis.

Jadi, Telegram adalah aplikasi berbasis komunikasi yang memiliki keunggulan jika dibandingkan aplikasi WhatsApp seperti bisa membuat grup melebihi dua ratus peserta, kemudian bisa menggirim file melebihi seratus $M B$. Terlepas dari kegunaanya sebagai aplikasi komunikasi.

Inovasi-inovasi proses pembelajaran melalui aplikasi mobile Telegram dari beberapa penelitian sebagai berikut:

Pertama dari penelitian Oki Ayunawati Fatmaya pada tahun 2019 yang berjudul "Penerapan Media Pembelajaran Menggunakan Aplikasi Telegram Terhadap Pencapaian Kompetensi mengidentifikasi Jenis Bahan Utama Pada Siswa Kelas XI Tata Busana Di SMKN 1 Buduran Tahun Pelajaran 2018-2019”. dalam Jurnal Tata Busana yang membahas mengenai kevalidan media pembelajaran Telegram dalam pemebelajaran yang diharapkan siswa dapat belajar secara mandiri dengan memanfaatkan fitur-fitur yang ada di Telegram.

Kedua dalam penelitian Bambang Karyadi pada tahun 2018 yang berjudul "Pemanfaatan Telegram Messenger Pada Pembelajaran Berbasis Blended Learning Di Smk Geo Informatika." Dalam Prosiding Sntp yang membahas mengenai pemanfaatan TIK khususnya aplikasi mobile yang sudah tersedia yaitu Telegram messenger untuk 
dimanfaatkan pada pembelajaran berbasis blended learning. Penarikan kesimpulan berdasarkan analisis teori-teori pembelajaran dan temuan data yang di peroleh melalui kegiatan pembelajaran yang telah dilakukan di SMK Geo Informatika.

Ketiga dalam penelitian Nur Ijazatin Septia pada tahun 2019 yang berjudul “Aplikasi Telegram (Tele-Edukasi) Dalam Pembelajaran IPA Di Madrasah Ibtidaiyah". Dalam jurnal PREMIERE: Journal of Islamic Elementary Education yang membahas mengenai pelaksanaan pembelajaran menggunakan aplikasi Telegram (tele-edukasi) untuk latihan mengerjaan soal IPA.

Jadi, kesimpulannya aplikasi mobile Telegram tidak hanya berfungsi sebagai aplikasi komunikasi saja namun juga bisa berfungsi sebagai aplikasi mobile pembelajaran yang sudah banyak di terapkan dan dilakukan inovasi pembelajaran yang membuat aplikasi mobile Telegram menjadi salah satu media pembelajaran yang digunakan dalam mendukung proses pembelajaran dimasa pandemi covid-19.

\section{Discord}

Menurut (Kusendi, 2020; Dewantara dkk, 2020) Discord adalah aplikasi gratis untuk mengakses obrolan yang mirip dengan Slack atau Skype yang memungkinkan pengguna untuk mengobrol secara real time menggunakan teks, suara atau video. Awalnya dibuat untuk video gamer untuk berinteraksi satu sama lain saat bermain game. Discord saat ini semakin populer dengan lebih dari seratus juta pengguna saat ini. Aplikasi ini menampung server atau ruang obrolan tentang berbagai topik, mulai dari game, musik, anime, dan meme cenderung menjadi yang paling populer.

Discord dapat diakses melalui komputer desktop, browser, atau dengan aplikasi seluler. Pengguna dapat mengatur atau bergabung dengan ruang obrolan, yang disebut Discord sebagai "Server". Pengguna dapat bergabung dengan grup yang telah diundang ke mereka atau membuat server obrolan pribadi mereka sendiri dan mengundang teman-teman mereka, kemudian dapat menggunakan teks, atau suara untuk mengobrol, dengan orang lain menggunakan server atau ruang obrolan itu. Ada juga server publik yang bisa diikuti siapa saja. 
Setiap server dapat dipecah menjadi "Channel", yang merupakan ruang yang lebih kecil atau ruang obrolan, untuk membahas topik tertentu. Server dan Channel ini juga mungkin memiliki tingkat izin akses yang berbeda untuk pengguna yang berbeda. Mulai dari memiliki izin untuk melarang pengguna lain, hingga memiliki kemampuan untuk mengunggah file dan gambar ke saluran.

Menurut Rakhmawan dkk (2020) Discord dapat digunakan dalam sistem berbasis windows, iOS, Android, Linux, bahkan Mac. Aplikasi discord memiliki berbagai fasilitas untuk berkomunikasi yang tidak dimiliki oleh aplikasi lain. Salah satunya fitur untuk berkomunikasi layaknya telepon. Fitur ini memungkinkan pendidik untuk menyampaikan materi secara leluasa kepada peserta didik. Fitur lain yang dimiliki Discord yaitu fitur video conference yang dapat digunakan untuk menyampaikan materi, berinteraksi antar video dengan para peserta didiknya. Selain itu dalam video conference ini pun pendidik dapat berbagi layar seperti halnya fitur yang dimiliki oleh aplikasi video conference lainnya seperti zoom cloud meeting, google meeting, atau cisco webex.

Jadi, aplikasi mobile Discord memiliki berbagai fasilitas untuk berkomunikasi layaknya telepon secara real time menggunakan teks, suara atau video yang target penggunanya tertuju pada pemain games. Pengguna dapat membuat channel atau server dan bisa menggundang pengguna lainnya untuk bergabung.

Inovasi-inovasi proses pembelajaran melalui aplikasi mobile Discord dari beberapa penelitian sebagai berikut:

Pertama penelitian dari Yurli Kusnedi pada tahun 2020 yang berjudul “Implementasi Problem Based Learning Berbantuan Aplikasi Discord Sebagai Upaya Peningkatan Hasil Belajar Komputer Dan Jaringan Dasar Materi Sistem Operasi Pada Siswa Kelas X TKJ SMKN 2 Sampit Tahun Pelajaran 2020/2021”. Dalam Penelitian Tindakan Kelas Program Pendidikan Profesi Guru (PPG) Universitas Negeri Malang yang membahas mengenai implementasi model pembelajaran Problem Based Learning (PBL) berbantuan aplikasi Discord dan media pembelajaran Flipbook sebagai upaya peningkatan hasil belajar pada mata pelajaran Komputer dan Jaringan Dasar materi Sistem Operasi pada siswa kelas X TKJ 3 SMK Negeri 2 Sampit. 
Kedua penelitian dari Rakhmawan dkk pada tahun 2020 yang berjudul "Analisis Pemanfaatan Aplikasi Discord Dalam Pembelajaran Daring Di Era Pandemi Covid-19”. Dalam Prosiding Seminar Nasional Pendidikan FKIP yang membahas mengenai potensi salah satu aplikasi media sosial yaitu Discord untuk digunakan di dalam pembelajaran secara daring di masa covid-19.

Ketiga penelitian dari Jagat Aditya Dewantara, Efriani dan Afandi pada tahun 2020 yang berjudul "Pemanfaatan Aplikasi Discord Sebagai Media Pembelajaran Online". Dalam JTIP: Jurnal Teknologi Informasi Dan Pendidikan yang membahas mengenai metode pembelajaran daring dengan menggunakan aplikasi Discord .

Jadi, aplikasi mobile Discord tidak hanya berfungsi sebagai aplikasi mobile komunikasi dan hiburan saja namun juga bisa berfungsi sebagai aplikasi mobile pembelajaran yang mana sudah banyak inovasi pembelajaran yang di terapkan dan dilakukan yang membuat aplikasi mobile Discord menjadi salah satu media pembelajaran yang digunakan dalam mendukung proses pembelajaran dimasa pandemi covid-19.

\section{Instagram}

Menurut Sari (2017) Instagram berasal dari pengertian dari keseluruhan fungsi aplikasi ini. Kata "insta" berasal dari kata "instan", seperti kamera polaroid yang pada masanya lebih dikenal dengan sebutan "foto instan". Instagram juga dapat menampilkan foto-foto secara instan, seperti polaroid di dalam tampilannya. Sedangkan untuk kata "gram" berasal dari kata "telegram" yang cara kerjanya untuk mengirimkan informasi kepada orang lain dengan cepat. Sama halnya dengan Instagram yang dapat mengunggah foto dengan menggunakan jaringan Internet, sehingga informasi yang ingin disampaikan dapat diterima dengan cepat. Oleh karena itulah Instagram merupakan gabungan dari kata instan dan telegram.

Sistem perteman di Instagram menggunakan istilah Following dan followers. Yang artinya following berarti mengikuti pengguna, dan followers berarti pengguna lain yang mengukuti akun. Setiap pengguna dapat berinteraksi dengan cara memberikan 
komentar dan memberikan respon (feedback) dengan like (suka) terhadap foto yang dibagikan.

Menurut Karimkhani (2014) instagram adalah outlet media sosial dengan pengguna yang terdiri dari individu, organisasi, vendor, dan bisnis, yang memposting foto mereka sendiri dan memposting ulang foto lainnya ke pengikut mereka. Aplikasi ini diluncurkan pada 6 Oktober 2010 ini awalnya dibuat khusus untuk pengguna iOS. Perusahaan kemudian melebarkan jangkauannya dengan merilis Instagram for Android pada April 2012. Kala itu, jumlah pengguna Instagram baru mencapai tiga puluh juta pengguna. Namun, karena dianggap sebagai jejaring sosial yang juga sangat kompetitif, seminggu kemudian Facebook secara resmi membeli aplikasi ini dengan biaya US\$ 1 miliar (sekitar Rp 9 triliun) (Innova, 2016).

Menurut Afrizal (2020) Instagram merupakan sosial media yang digunakan untuk membagikan foto atau video yang menarik untuk dilihat oleh orang yang tergabung di Instagram. Salah satu fitur Instagram adalah penambahan teks yang biasa disebut caption untuk menjelaskan tentang gambar atau video yang diunggah.

Inovasi-inovasi proses pembelajaran melalui aplikasi mobile Instagram dari beberapa penelitian sebagai berikut:

Pertama dari penelitia Meutia Puspita Sari pada tahun 2017 yang berjudul "Fenomena Penggunan Media Sosial Instagram Sebagai Komunikasi Pembelajaran Agama Islam Oleh Mahasiswa Fisip Universitas Riau”. Dalam jurnal JOM FISIP yang membahas mengenai motif yang dilakukan oleh pengguna Instagram sebagai komunikasi pembelajaran agama islam akan dikategorikan menjadi dua motif, yaitu: inorder-to-motive (motif masa akan datang) dan because motives (motif masa lalu).

Kedua dari penelitian Rina Putri Utami, Riezky Maya Probosari dan Umi Fatmawati pada tahun 2015 yang berjudul "Pengaruh Model Pembelajaran Project Based Learning Berbantu Instagram Terhadap Kemampuan Berpikir Kreatif Siswa Kelas X SMA Negeri 8 Surakarta”. Dalam jurnal Bio-Pedagog yang membahas mengenai kemampuan berpikir kreatif (KBK) siswa yang diperoleh dari nilai postes yang berasal dari dua kelas, yaitu satu kelas eksperimen dan satu kelas kontrol serta data 
pendukung berupa data aspek sikap siswa. Kelas eksperimen dengan menerapkan Project-Based Learning berbantu Instagram dan kelas kontrol dengan menerapkan model pembelajaran konvensional yaitu ceramah dan diskusi.

Ketiga dari penelitian Dimas Yusuf Afrizal pada tahun 2020 yang berjudul "Media Sosial Instagram sebagai Sarana Pembelajaran Menulis Teks Deskripsi”. Dalam PROSIDING SAMASTA yang membahas mengenai pemanfaatkan Instagram sebagai media pembelajaran teks deskripsi. Inti artikel ini untuk menjelaskan bagaimana media Instagram dapat digunakan sebagai media pembelajaran teks deskripsi dan menjadi pijakan untuk belajar membuat teks deskripsi di Instargam sehingga menyenangkan bagi pelajar.

Jadi, aplikasi mobile Instagram tidak hanya berfungsi sebagai aplikasi mobile media sosial atau hiburan saja namun juga bisa berfungsi sebagai aplikasi mobile pembelajaran yang sudah banyak di terapkan dan dilakukan inovasi pembelajaran yang membuat aplikasi mobile Instagram menjadi salah satu media pembelajaran yang digunakan dalam mendukung proses pembelajaran dimasa pandemi covid-19.

\section{Facebook}

Menurut (Sasmito, 2015; Luthfiyanti, 2020) Facebook adalah salah satu aplikasi media sosial yang memiliki fitur-fitur yang digunakan untuk berkomunikasi dengan pengguna lainnya, mulai dari pendidikan, bisnis, dan entertaiment. Banyak kegiatan kehidupan yang dikembangkan di situs jejaring sosial ini. Facebook sangat berkembang pesat di kalangan remaja dewasa. Keunggulan facebook mudah diakses, baik melalui komputer, laptop, tablet, maupun telepon genggam (hand phone). Facebook menduduki peringkat pertama sebagai media sosial yang terlaris diantara media sosial lainnya.

Kemudian Facebook adalah sebuah layanan jejaring sosial yang diluncurkan pada bulan Februari 2004, dimiliki dan dioperasikan oleh Facebook. Inc. Facebook didirikan oleh Mark Zuckerberg bersama teman sekamarnya dan sesama mahasiswa Universitas Harvard, Eduardo Saverin, Andrew Mc Collum, Dustin Moskovitz dan Chris Hughes. Popularitasnya kemudian mendunia dan menjadi salah satu jejaring sosial paling populer saat ini. Facebook memungkinkan penggunanya membuat profil diri, 
memutakhirkan profilnya dengan informasi pribadi, misalnya alamat rumah, nomor ponsel, hobi, dan pandangan keagamaan. Selain membuat profil diri, pengguna Facebook juga bisa mendaftarkan pengguna lain sebagai teman yang bisa dikirimi pesan, bergabung dalam grup atau kelompok tertentu, mengirimkan dan/atau menandai gambar, serta meninggalkan komentar terhadap gambar yang dikirimi pengguna lain

Inovasi-inovasi proses pembelajaran melalui aplikasi mobile Facebook dari beberapa penelitian sebagai berikut:

Pertama penelitian dari Mustika Fitri Larasati Sibuea, Muhammad Ardiansyah Sembiring dan Raja Tama Andri Agus pada tahun 2020 yang berjudul "Efektivitas Pembelajaran Daring Berbasis Media Sosial Facebook Dalam Meningkatkan Hasil Belajar". Dalam Journal of Science and Social Research yang membahas mengenai pembelajaran daring berbasis media sosial Facebook lebih efektif dibandingkan pembelajaran daring biasa dan untuk mengetahui apakah peningkatan hasil belajar siswa yang diberi pembelajaran daring berbasis media sosial facebook lebih tinggi dari pada peningkatan hasil belajar siswa yang diberi pembelajaran daring biasa.

Kedua penelitian dari Lita Luthfiyanti pada tahun 2020 yang berjudul "Pemanfaatan Media Sosial Facebook dalam Pembelajaran Bahasa Indonesia di Sekolah". Dalam Prosiding Seminar Nasional Linguistik VII yang membahas mengenai solusi alternatif bagi permasalahan pembelajaran dengan media facebook sehigga pembelajaran bahasa Indonesia lebih fleksibel, tidak terbatas oleh waktu, ruang kelas, dan tatap muka intensif sebagai mana di sekolah.

Ketiga penelitian dari Mayasari Sasmito pada tahun 2015 yang berjudul "Pemanfaatan Media Sosial "Facebook" Untuk Media Pembelajaran Bahasa Indonesia”. Dalam Jurnal Media APLIKOM yang membahas megenai Penggunaan Facebook sebagai media pembelajaran dalam solusi alternatif bagi permasalahan pembelajaran sehingga pembelajaran bahasa Indonesia lebih fleksibel, tidak terbatas oleh waktu, ruang kelas, dan tatap muka intensif sebagaimana di sekolah. Dengan cara mengoptimalkan fitur/aplikasi yang ada pada Facebook (chating, forum diskusi, pesan, tautan/ link dengan situs lain, grup, dan games quiz) sebagai media pembelajaran yang menarik dan dekat dengan peserta didik. 
Jadi, aplikasi mobile Facebook tidak hanya berfungsi sebagai aplikasi mobile berbasis media sosial dan hiburannya saja namun juga bisa berfungsi sebagai aplikasi mobile pembelajaran yang mana sudah banyak inovasi pembelajaran di terapkan dan dilakukan yang membuat aplikasi mobile Facebook menjadi salah satu media pembelajaran yang digunakan dalam mendukung proses pembelajaran dimasa pandemi covid-19.

\section{YouTube}

Menurut (Sianipar, 2013; lestari, 2017; Pratiwi \& Hapsari, 2020) YouTube adalah salah satu layanan berbagi video di internet yang paling popular saat ini. YouTube sebagai sebuah situs web video sharing (berbagi video) yang memungkinkan para pengguna menggunggah, mencari video, menonton, diskusi/tanya jawab dan berbagi klip video secara gratis. Video-video tersebut adalah video klip, film, TV, serta video buatan para pengguna. YouTube menjadi situs online video provider paling dominan di dunia dan tidak membatasi durasi untuk mengunggah video.

Keunggulan lain, YouTube menawarkan layanan gratis khususnya untuk menikmati dan mengakses video-video yang masuk dalam sistemnya. Untuk mengakses video pengguna tidak perlu memiliki akun premium atau membayar sejumlah uang dalam skala waktu tertentu. Pengguna dapat mengakses video-video tersebut secara gratis. Pengguna YouTube dapat mengunduh beberapa video dan setelah berhasil, video dapat disimpan di gadget masing-masing untuk dinikmati kapan tanpa menggunakan sambungan internet.

Inovasi-inovasi proses pembelajaran melalui aplikasi mobile YouTube dari beberapa penelitian sebagai berikut:

Pertama penelitian dari Brillianing Pratiwi dan Kusnindyah Puspito Hapsar pada tahun 2020 yang berjudul "Kemampuan Berpikir Tingkat Tinggi Dalam Pemanfaatan YouTube Sebagai Media Pembelajaran Bahasa Indonesia”. Dalam Jurnal Ilmiah Sekolah Dasar yang membahas mengenai pemanfaatan YouTube sebagai media pembelajaran bahasa Indonesia kemudian sebagai stimulus sebelum pemberian soal 
High Order Thinking Skill dan juga sebagai pemanfaatan terhadap kemampuan berpikir siswa.

Kedua penelitian dari Renda Lestari pada tahun 2017 yang berjudul "Pengunaan YouTube Sebagai Media Pembelajaran Bahasa Inggris". Dalam Seminar Nasional Kedua Pendidikan Berkemajuan dan Menggembirakan yang membahas mengenai sejauh mana YouTube dapat digunakan sebagai media pembelajaran dalam matakuliah Bahasa Inggris. Hasil penelitian menunjukkan bahwa video yang ada di YouTube dapat digunakan sebaga salah satu media pembelajaran.

Ketiga penelitian dari Dwi Iga Luhsasi dan Arief Sadjiarto pada tahun 2017 yang berjudul "YouTube: Trobosan Media Pembelajaran Ekonomi Bagi Mahasiswa”. Dalam Jurnal Ekonomi Pendidikan dan Kewirausahaan yang membahas mengenai pengembangan media pembelajaran berbasis YouTube untuk materi ekonomi akuntansi.

Jadi, aplikasi mobile YouTube tidak hanya berfungsi sebagai aplikasi mobile media streaming dan hiburan saja namun juga bisa berfungsi sebagai aplikasi mobile pembelajaran yang mana sudah banyak inovasi pembelajaran yang di terapkan dan dilakukan yang membuat aplikasi mobile YouTube menjadi salah satu media pembelajaran yang digunakan dalam mendukung proses pembelajaran dimasa pandemi covid-19.

\section{TikTok}

Menurut (Aji \& Setiyadi, 2020; Warini, 2020) Aplikasi TikTok adalah sebuah jejaring sosial dan platform video musik asal negeri Tiongkok yang diluncurkan pada awal September 2016. Aplikasi tersebut memberi akses kepada para pemakai untuk membuat video musik pendek mereka sendiri.

Menurut Bohang (dalam Dewanta 2020), menunjukkan sepanjang kuartal pertama (Q1) 2018, TikTok menjadi aplikasi paling banyak diunduh yakni 45,8 juta kali. Jumlah itu mengalahkan aplikasi popular lainnya, seperti YouTube, WhatsApp, Facebook, dan Instagram. Jumlah itu mengalahkan aplikasi popular lainnya, semacam YouTube, WhatsApp, Facebook, dan Instagram. Sekitar sepuluh juta pengguna aktif aplikasi TikTok di Indonesia, mayoritas adalah anak milenial, usia sekolah, atau biasa 
dikenal dengan generasi Z. Kemudian Pada 3 Juli 2018 aplikasi TikTok pernah di blokir di Indonesia. Kemenkominfo telah melakukan pemantauan mengenai aplikasi TikTok selama sebulan dan mendapati banyak laporan keluhan tentang aplikasi ini. Terhitung hingga 3 Juli, laporan dan keluhan yang masuk mencapai 2.853. Menurut menteri Rudiantara, terdapat banyak sekali konten negatif terutama untuk anak-anak.

Tetapi dengan berbagai pertimbangan dan regulasi yang baru maka pada bulan Agustus 2018 aplikasi TikTok resmi dapat diunduh kembali. Salah satu regulasi yang ditengarai adalah, batas usia pengguna TikTok yaitu minimal usia sebelas tahun. Terlepas dari kontrovesi tersebut, melihat fakta bahwa jumlah pengguna TikTok yang mencapai sepuluh juta lebih di Indonesia dan mayoritas merupakan anak usia sekolah (generasi milenial), maka dapat disimpulkan bahwa aplikasi TikTok merupakan aplikasi primadona, menarik, dan digandrungi oleh para milenial. TikTok dapat diolah menjadi media pembelajaran yang menarik dan interaktif bagi siswa. Aplikasi TikTok dapat diimplementasikan dalam pembelajaran Bahasa Indonesia sebagai media.

Inovasi-inovasi proses pembelajaran melalui aplikasi mobile TikTok dari beberapa penelitian sebagai berikut:

Pertama penelitian dari AANBJ Dewan pada tahun 2020 yang berjudul "Pemanfaatan Aplikasi TikTok Sebagai Media Pembelajaran Bahasa Indonesia". Dalam Jurnal Pendidikan dan Pembelajaran Bahasa Indonesia yang membahas mengenai pemanfaatan aplikasi TikTok sebagai media dalam pembelajaran Bahasa Indonesia.

Kedua penelitian dari Wisnu Nugroho Aji dan Dwi Bambang Putut Setiyadi pada tahun 2020 yang berjudul "Aplikasi TikTok Sebagai Media Pembelajaran Keterampilan Bersastra”. Dalam Jurnal METAFORA yang membahas mengenai Aplikasi TikTok bersama dengan pengunaan metode dan teknik yang tepat, dapat dimanfaatkan sebagai media pembelajaran interaktif pada pembelajaran dan pengajaran bahasa dan sastra Indonesia.

Ketiga penelitian dari Ni Luh Warini, Ni Putu Elsa Sukma Dewi, Putu Chris Susanto dan Putu Chrisma Dewi pada tahun 2020 yang berjudul "Daya Tarik Tiktok Sebagai Media Pembelajaran Bahasa Inggris Online”. Dalam Seminar Ilmiah Nasional 
Teknologi, Sains, dan Sosial Humaniora (SINTESA) yang membahas mengenai menggambarkan fenomena meluasnya penggunaan media sosial sebagai media pembelajaran bahasa Inggris online. Ini berfokus pada membahas daya tarik TikTok bagi generasi milenial dan generasi $\mathrm{Z}$ untuk belajar bahasa Inggris melalui konten video daring yang disajikan oleh content creator terbaik di bawah tagar populer \#learnenglish.

Jadi, aplikasi mobile TikTok tidak hanya berfungsi sebagai aplikasi mobile hiburan saja namun juga bisa berfungsi sebagai aplikasi mobile pembelajaran yang mana sudah banyak di terapkan dan dilakukan yang membuat aplikasi mobile TikTok menjadi salah satu media pembelajaran yang digunakan dalam mendukung proses pembelajaran dimasa pandemi covid-19.

\section{Zoom Meeting}

Menurut Haqien dan Rahman (2020) Zoom Meeting sendiri merupakan sebuah media pembelajaran menggunakan video. Pendiri aplikasi Zoom Meeting yaitu Eric Yuan yang diresmikan tahun 2011 yang kantor pusatnya berada di San Jose, California. Aplikasi ini tidak hanya digunakan untuk pembelajaran saja tetapi bisa digunakan untuk urusan perkantoran maupun urusan lainnya. Platfrom ini gratis jadi dapat digunakan oleh siapapun dengan batas waktu empat puluh menit dan tidak ada batasan waktu jika akun kita berbayar. Dalam aplikasi Zoom Meeting ini kita bisa berkomunikasi langsung dengan siapapun lewat video. Oleh karena itu, memang cocok digunakan sebagai media pembelajaran.

Menurut Angelina dan Rahadi (2020) Zoom Meeting adalah aplikasi yang menyediakan layanan konfersi atau meeting jarak jauh yang berkonsep screen sharing. Aplikasi ini tidah hanya mampu satu panggilan video, tetapi mampu memanggil panggilan grup sampai seratus partisipan. Zoom mempunyai fitur basic yaitu partisipan bisa sampai seratus orang dengan waktu meeting empat puluh menit yang bisa didapatkan secara gratis, untuk menikmati fitur yang lebih banyak bisa berlangganan dengan zoom business. 
Menurut Mahayoni (2020) Aplikasi Zoom Meeting adalah aplikasi komunikasi dengan menggunakan video. Aplikasi tersebut dapat digunakan dalam berbagai perangkat seluler, desktop, hingga telepon dan sistem ruang.

Inovasi-inovasi proses pembelajaran melalui aplikasi mobile Zoom Meeting dari beberapa penelitian sebagai berikut:

Pertama penelitian dari Lusy Angelina dan Dedi Rianto Rahadi pada tahun 2020 yang berjudul "Strategi Pengelolaan Zoom Meeting Dalam Proses Pembelajaran Dimasa Pandemi”. Dalam Jurnal Pendidikan Teknologi Informasi yang membahas mengenai informasi kepada pengguna bagaimana strategi mengelola Zoom Meeting dalam proses pembelajaran dan bekerja dari rumah di masa pandemi.

Kedua penelitian dari Ni Made Sri Mahayoni pada tahun 2020 yang berjudul "Penggunaan Aplikasi Zoom Meeting Pada Pembelajaran Agama Hindu Di Masa Pandemi”. Dalam Jurnal Widya Sastra Pendidikan Agama Hindu yang membahas mengenai kemajuan teknologi memberikan dampak besar terhadap perkembangan pendidikan, para pendidik memanfaatkanya untuk mempermudah proses belajar mengajar serta meningkatkan kualitas pendidikan. Berbagai metode dan strategi bisa dimanfaatkan untuk melaksanakan pembelajaran walaupun dalam kondisi pandemi yang sedang dialami oleh negara kita. Pembelajaran daring menjadi salah satu solusi layanan pendidikan yang dilakukan pemerintah dalam menangani dan memutuskan rantai penyebaran covid-19, sehingga siswa tetap belajar walaupun dirumah saja.

Ketiga penelitian dari Danin Haqien dan Aqiilah Afiifadiyah Rahman pada tahun 2020 yang berjudul "Pemanfaatan Zoom Meeting Untuk Proses Pembelajaran Pada Masa Pandemi Covid-19”. Dalam SAP (Susunan Artikel Pendidikan) yang membahas mengenai seberapa efektifnya penggunaan aplikasi Zoom Meeting terhadap para mahasiswa di Jakarta dan Depok ketika pandemi Covid-19.

Jadi, aplikasi mobile Zoom Meeting memang difungsikan sebagai sebagai aplikasi mobile pembelajaran dan meeting untuk pekerjaan yang mana sudah banyak inovasi pembelajaran di terapkan dan dilakukan yang membuat aplikasi mobile Zoom Meeting menjadi salah salah satu media pembelajaran yang digunakan dalam mendukung proses pembelajaran dimasa pandemi covid-19. 


\section{Google Classroom}

Menurut Mu'minah \& Gaffar (2020) Aplikasi Google Classroom memang telah digunakan dalam metode pembelajaran di dunia barat sebagai penunjang dalam kegiatan pembelajaran dan bentuk support terhadap kemajuan teknologi saat ini. Pengaplikasian Google Classroom sangat mudah digunakan dalam kegiatan pembelajaran bahkan di bulan maret 2017 Google Classroom dapat diakses oleh semua orang melalui google pribadi. Aplikasi Google Classroom ini dapat diunduh secara gratis di perangkat berbasis android maupun iOS. Seperti yang telah diketahui bahwa kedua basis smartphone tersebut telah menjadi kebutuhan pokok di generasi 2020 ini. Beberapa fitur yang dapat dimanfaatkan guru pada Google Classroom adalah assignment, grading, communication, timecost. Archive course, mobile application dan privacy.

Google Classroom adalah aplikasi khusus yang digunakan untuk pembelajaran online yang dapat digunakan dari jarak jauh sehingga memudahkan guru untuk membuat, mengelompokkan dan membagikan tugas selain itu guru dan siswa bisa setiap saat melakukan kegiatan pembelajaran melalui kelas online Google Clasroom dan siswa nantinya juga dapat belajar, menyimak, membaca dan mengirim tugas dari jarak jauh.

Google Classroom adalah layanan berbasis internet yang disediakan Google sebagai sebuah system elearning. Google Classroom menjadi teknologi komunikasi paling utama dalam kegiatan proses pembelajaran. Kehebatan teknologi komunikasi ditandai dengan hadirnya metode e-learning. Google classroom merupakan sarana memperlancar komunikasi jarak jauh antara pengajar dan siswa terutama dalam kelas pengelolaan konten Digital. Sarana belajar bersama, menerima dan membaca materi, mengirimkan tugas secara jarak jauh hingga menyajikan nilai tugas secara transparansi. Google Classroom merupakan aplikasi tak berbayar, sehingga Google Classroom dianggap sangat cocok untuk digunakan di negara-negara berkembang, atau secara khusus dapat digunakan oleh sekolah-sekolah yang memiliki keterbatasan biaya dalam pengembangan penggunaan ICT dalam proses pembelajarannya. 
Inovasi-inovasi proses pembelajaran melalui aplikasi mobile Google Classroom dari beberapa penelitian sebagai berikut:

Pertama penelitian dari Iim Halimatul Mu'minah dan Aden Arif Gaffar pada tahun 2020 yang berjudul "Optimalisasi Penggunaan Google Classroom Sebagai Alternatif Digitalisasi Dalam Pembelajaran Jarak Jauh (PJJ)”. Dalam Jurnal Bio Educatio yang membahas mengenai manfaat dan informasi mengenai optimalisasi penggunaan Google Classroom sebagai alternatife digitalisasi dalam pembelajaran jarak jauh sebagai solusi dalam melaksanakan proses pembelajaran daring

Kedua penelitian dari Rafika Dewi Nasution, Farida Hanim Saragih dan Puan Suri Mira A. Sembiring pada tahun 2020 yang berjudul "Pendampingan Sistem Pembelajaran Online Berbasis Aplikasi Google Meet Bagi Guru-Guru Smp It Daarul Istiqlal Dan SMP IT Rahmat Marindal I, Kecamatan Patumbak, Kabupaten Deli Serdang”. Dalam Jurnal Pengabdian Kepada Masyarakat yang membahas mengenai pembelajaran online dapat meningkatkan proses belajar mahasiswa yang lebih mandiri, kreatif serta inovatif. Apabila materi yang disampaikan pada Google Meeting dirancang secara detail, dan sistematis, maka pembelajaran dapat meningkatkan kualitas pengetahuan siswa.

Ketiga penelitian dari Diah Aryani, Malabay, Hani Dewi Ariessanti dan Syahrizal Dwi Putra pada tahun 2020 yang berjudul "Pelatihan Pemanfaatan Google Classroom untuk Mendukung Kegiatan Pembelajaran Daring saat Pandemi COVID-19 di SMPIT Insan Rabbani”. Dalam Jurnal Abdidas yang membahas mengenai pemahaman dan kemampuan dalam memanfaatkan layanan Google Classroom yang merupakan salah satu aplikasi pendukung pembelajaran daring. Sehingga layanan Google Classroom dapat menjadi salah satu alternatif bagi para guru dalam memilih aplikasi pendukung pembelajaran daring selama masa pandemi ini dan kegiatan pembelajaran dapat berjalan dengan baik.

Jadi, aplikasi mobile Google Classroom memang difungsikan sebagai sebagai aplikasi mobile pembelajaran yang mana sudah banyak inovasi pembelajaran di terapkan dan dilakukan yang membuat aplikasi mobile Google Classroom menjadi 
salah satu media pembelajaran yang digunakan dalam mendukung proses pembelajaran dimasa pandemi covid-19.

\section{Penutup}

Pada masa pandemi covid-19 Aplikasi mobile sekarang sudah sangat banyak digunakan dan juga tersedia secara gratis. Apalagi saat ini smartphone semakin mudah didapatkan. Aplikasi mobile sangatlah beragam kegunaannya salah satunya sebagai media pembelajaran.

Aplikasi mobile berbasis komunikasi, sosial, hiburan, streaming, pembelajaran dan lain-lain seperti Instagram, Facebook, Telegram, YouTube, TikTok, Zoom Meeting, Google Classroom, Discord, dan lain-lain. Semua aplkasi mobile ini bisa di gunakan dalam pembelajaran dengan inovasi-inovasi yang sudah banyak diterapkan dalam menunjang proses pembelajaran dimasa pandemi covid-19. Karenanya guru harus bisa memanfaatkan perkembangan teknologi salah satunya aplikasi mobile dan juga guru harus bisa berinovasi dalam pembelajaran agar bisa membuat proses pembelajaran yang dilakukan menjadi menarik, mudah dan juga dapat meningkatkan kualitas belajar peserta didik. 


\section{Referensi}

Abdullah M. R. T. L, Azelin M. N. (2010). M-Learning: Changing Roles Of Instructors And Learners. IJAS, 3(14), 83-95.

Aji, W. N., \& Setiyadi, D. B. P. (2020). Aplikasi TikTok Sebagai Media Pembelajaran Keterampilan Bersastra. Metafora: Jurnal Pembelajaran Bahasa Dan Sastra, 6(2), 147-157.

Afandi, R. S., \& Saputra, E. H. (2013). Aplikasi Mobile Informasi Kafe 24 Jam Di Yogyakarta Berbasis Android. Data Manajemen dan Teknologi Informasi (DASI), 14(3), 49.

Afrizal, D. Y. (2020). Media Sosial Instagram Sebagai Sarana Pembelajaran Menulis Teks Deskripsi. Prosiding Samasta.

Angelina, L. (2020). Strategi Pengelolaan Zoom Meeting Dalam Proses Pembelajaran Dimasa Pandemi. Jurnal Pendidikan Teknologi Informasi (JUKANTI), 3(2), 27 32.

Dewanta, A. (2020). Pemanfaatan Aplikasi TikTok Sebagai Media Pembelajaran Bahasa Indonesia. Jurnal Pendidikan dan Pembelajaran Bahasa Indonesia, 9(2), 79-85.

Efriani, E., Dewantara, J. A., \& Afandi, A. (2020). Pemanfaatan Aplikasi Discord Sebagai Media Pembelajaran Online. JTIP: Jurnal Teknologi Informasi Dan Pendidikan, 13(1), 61-65.

Fatmaya O. A., \& Marniati. (2019). Penerapan Media Pembelajaran Menggunakan Aplikasi Telegram Terhadap Pencapaian Kompetensi mengidentifikasi jenis Bahan utama Pada Siswa Kelas Xi Tata Busana Di Smkn 1 Buduran Tahun Pelajaran 2018-2019. Jurnal Tata Busana, 8(3), 88-93.

Fathurahman, N. (2020). Inovasi Pembelajaran Daring Pada Masa Pandemi Covid-19. Prosiding Seminar Nasional Pendidikan FKIP, 3(1), 615-627.

Hartini, Hapsari S., Wibawanto W. H., \& Sudana. I. M. (2017). Pengembangan Mobile Learning Teknik Digital Bagi Mahasiswa Pendidikan Teknik Elektro. Journal of Vocational and Career Education, 2(1), 28-36.

Irsan, M. (2015). Rancang Bangun Aplikasi Mobile Notifikasi Berbasis Android Untuk Mendukung Kinerja Di Instansi Pemerintahan. JustIN (Jurnal Sistem dan Teknologi Informasi), 3(1), 115-120. 
Iriansyah, H. S. (2020). Membangun Kreatifitas Guru Dengan Inovasi Pembelajaran Di Masa Pandemi Covid-19. dalam Prosiding Seminar Nasional Pendidikan STKIP Kusuma Negara II (pp. 1-6).

Indaryani, E., \& Suliworo, D. (2018). Dampak Pemanfaatan Whatsapp Dalam Meningkatkan Motivasi Belajar Siswa Pada Pelajaran Fisika. dalam Quantum: Seminar Nasional Fisika, dan Pendidikan Fisika (pp. 25-31).

Innova, E., I. (2016). Motif dan Kepuasan Pengguna Instagram di Komunitas Instameet Indonesia. Jurnal E-Komunikasi 4(1): 1-11.

Karimkhani, C., Connet, J., \&n Boyers, L. (2001). Dermatology on Instagram. Dermatology Online Journal, 20(7), 24-42.

Kusworo, K., Rusmaini, R., Sholeh, B., \& Jaya, F. (2019). Pembaharuan Pembelajaran Pendidikan Ekonomi. Banten:UNPAM Press.

Kusnedi, Y. (2020). Implementasi Problem Based Learning Berbantuan Aplikasi Discord Sebagai Upaya Peningkatan Hasil Belajar Komputer Dan Jaringan Dasar Materi Sistem Operasi Pada Siswa Kelas X TKJ SMKN 2 Sampit. Penelitian Tindakan Kelas Program Pendidikan Profesi Guru (PPG) Universitas Negeri Malang.

Lestari, R. (2017). Pengunaan Youtube sebagai Media Pembelajaran Bahasa Inggris. Prosiding Seminar Nasional Pendidikan Berkemajuan dan Menggembirakan (The Progressive \& Fun Education Seminar) ke-2.

Lubis, M., \& Yusri, D. (2020). Pembelajaran Pendidikan Agama Islam Berbasis ELearning (Studi Inovasi Pendidik MTS. PAI Medan di Tengah Wabah Covid19). Fitrah: Journal of Islamic Education, 1(1), 1-18.

Luhsasi, D. I., \& Sadjiarto, A. (2017). Youtube: Trobosan Media Pembelajaran Ekonomi Bagi Mahasiswa. Jurnal Ekonomi Pendidikan dan Kewirausahaan, 5(2), 219-229.

Luthfiyanti, L. (2018). Pemanfaatan Media Sosial Facebook dalam Pembelajaran Bahasa Indonesia di Sekolah. Prosiding Seminar Nasional Linguistik VII.

Lu'mu. (2017). Learning Media Of Applications Design Based Android Mobile Smartphone. International Journal of Applied Engineering Research, 12(17), 6576- 6585 . 
Layona, R., \& Yulianto, B. (2016). Aplikasi Pencarian Informasi Dan Lokasi Tempat Makan Pada Perangkat Mobile Berbasis Android. Jurnal Nasional Teknologi dan Sistem Informasi, 2(2), 9-16.

Mahayoni, N. M. S. (2020). Penggunaan Aplikasi Zoom Meeting Pada Pembelajaran Agama Hindu Di Masa Pandemi. Jurnal Widya Sastra Pendidikan Agama Hindu, 3(1), 47-53.

Nasution, R. D., Saragih, F. H., \& Sembiring, P. S. M. A. (2020). Pendampingan Sistem Pembelajaran Online Berbasis Aplikasi Google Meet Bagi Guru-Guru Smp It Daarul Istiqlal Dan SMP IT Rahmat Marindal I, Kecamatan Patumbak, Kabupaten Deli Serdang. Jurnal Pengabdian Kepada Masyarakat, 26(4), 188-194.

Nurdyansyah \& Widodo, A. (2018). Inovasi Teknologi Pembelajaran. Sidoarjo: Nizamia Learning Center.

Nugraheni, A. S. (2020). Metode Pembelajaran Melalui Whatsapp Group Sebagai Antisipasi Penyebaran Covid-19 pada AUD di TK ABA Kleco Kotagede. PAUDIA: Jurnal Penelitian dalam Bidang Pendidikan Anak Usia Dini, 9(1), 126-130.

Pengelola Web Kemdikbud. (2020). Mendikbud Terbitkan SE tentang Pelaksanaan Pendidikan dalam Masa Darurat Covid-19. https://www.kemdikbud.go.id/main/blog/2020/03/mendikbud-terbitkan-setentang-pelaksanaan-pendidikan-dalam-masa-darurat-covid19. (diakses pada 6 Januari 2021).

Prajana, A. (2017). Pemanfaatan aplikasi whatsapp dalam media pembelajaran di uin ar-raniry banda aceh. Cyberspace: Jurnal Pendidikan Teknologi Informasi, 1(2), 122-133.

Pratiwi, B., \& Hapsari, K. P. (2020). Kemampuan Berpikir Tingkat Tinggi Dalam Pemanfaatan YouTube Sebagai Media Pembelajaran Bahasa Indonesia. Jurnal Ilmiah Sekolah Dasar, 4(2), 282-289.

Rohmah, N. (2014). Inovasi Strategi Pembelajaran PAI dalam Meningkatkan Mutu Pendidikan PAI. Madrasah. Jurnal Pendidikan dan Pembelajaran Dasar, 6(2), pp.24.

Rakhmawan, A., Juansah, D. E., Nulhakim, L., Biru, L. T., Rohimah, R. B., Suryani, D. I., \& Resti, V. D. A. (2020). Analisis Pemanfaatan Aplikasi Discord Dalam Pembelajaran Daring Di Era Pandemi Covid-19. Dalam Prosiding Seminar Nasional Pendidikan FKIP (Vol. 3, No. 1, pp. 55-59). 
Surahman, S., \& Setiawan, E. B. (2017). Aplikasi Mobile Driver Online Berbasis Android Untuk Perusahaan Rental Kendaraan. Ultima InfoSys: Jurnal Ilmu Sistem Informasi, 8(1), 35-42.

Sa’ud, Udin. (2011). Inovasi pendidikan. Bandung: ALFABETA.

Septia, N. I. (2019). Aplikasi Telegram (Tele-Edukasi) Dalam Pembelajaran IPA Di Madrasah Ibtidaiyah. Premiere: Journal Of Islamic Elementary Education, 1(1), $37-48$.

Sibuea, M. F. L., Sembiring, M. A., \& Agus, R. T. A. (2020). Efektivitas Pembelajaran Daring Berbasis Media Sosial Facebook Dalam Meningkatkan Hasil Belajar. Journal Of Science And Social Research, 3(1), 73-77.

Sasmito, M. (2015). Pemanfaatan Media Sosial" Facebook" Untuk Media Pembelajaran Bahasa Indonesia. Media Aplikom, 4(4), 38-52.

Sianipar, A., P. (2013). Pemafaatan YouTube di Kalangan Mahasiswa. Flow, 2(2), 1-10.

Trisnadoli, A. (2015). Analisis Kebutuhan Kualitas Perangkat Lunak Pada Software Game Berbasis Mobile. Jurnal Komputer Terapan, 1(2), 1-8.

Utami, R. P., Probosari, R. M., \& Fatmawati, U. M. I. (2015). Pengaruh Model Pembelajaran Project Based Learning Berbantu Instagram Terhadap Kemampuan Berpikir Kreatif Siswa Kelas X SMA Negeri 8 Surakarta. Bio-Pedagogi,4(1), 47-52.

Zulhafizh, S. P., \& Permatasari, S. Developing Quality Of Learning In The Pandemic Covid-19 Through Creative And Critical Thinking Attitudes. (2020). JURNAL PAJAR (Pendidikan dan Pengajaran), 4(5), 937-949.

Zulhafizh, Atmazaki, \& Syahrul R. (2013). Kontribusi Sikap dan Motivasi Belajar Siswa terhadap Hasil Belajar Bahasa Indonesia. Jurnal Bahasa, Sastra dan Pembelajaran, 1(2), 13-28. 


\section{Data Penulis}

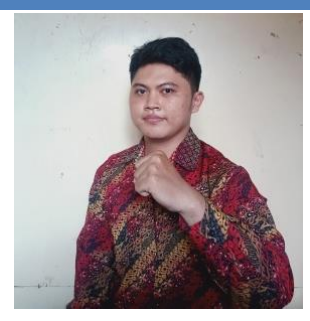

Sidiq Aditia, lahir dan dibesarkan di Dabo Singkep, Pada 2 Maret 1998. Meneyelesaikan pendidikan dasar sampai menegah atas di tanah kelahirannya. Kemudian pada tahun 2018, Ia melanjutkan studi pada strata satu Jurusan Pendidikan Bahasa dan Seni di Progam studi Pendidikan Bahasa dan Sastra Indonesia, FKIP, Universitas Riau. Melalui Jalur SBMPTN (Seleksi Bersama Masuk Perguruan Tinggi Negeri). Prestasi yang diraih menjadi panitia bulan bahasa dan pratikum sastra Pendidikan Bahasa dan Sastra Indonesia, FKIP, Universitas Riau. Kemudian pernah menjabat menjadi wakil ketua Himpunan Mahasiswa Pendidikan Bahasa dan Sastra Indonesia, FKIP, Universitas Riau, Priode 2019 sampai 2020.

Kontak

No WA: +6282268846022

Email : sidiqaditia@gmail.com 